Review Paper http://ajol.info/index.php/ijbcs http://indexmedicus.afro.who.int

\title{
Diversity, biology and exploitation of brackish water crabs in West Africa: A review
}

\author{
Comlan Eugène DESSOUASSI ${ }^{1,2^{*}}$, Antoine CHIKOU ${ }^{1}$, Djiman LEDEROUN ${ }^{1}$, \\ Delphine ADANDEDJAN ${ }^{1}$, Luc GANGBE ${ }^{2}$ and Philippe LALEYE ${ }^{1}$ \\ ${ }^{I}$ Laboratory of Hydrobiology and Aquaculture, Faculty of Agronomic Science, \\ University of Abomey-Calavi. 01 BP 526 Tri Postal Cotonou, Benin. \\ ${ }^{2}$ Benin National Institute for Agricultural Research. 04BP626 Cotonou, Benin. \\ "Corresponding author; E-mail: dessouassieugene@ hotmail.fr; Tel: +229 97580352/+22994735052
}

\begin{abstract}
Crabs are an important biological component of the West African lagoon fauna and are exploited by fishing communities. This paper presents a synthesis of the current understanding pertaining to the diversity, biology and exploitation of these crabs in order to identify promising research paths for this zoological group. A literature review was done. Thirty-two species belonging to thirteen families and twenty-three genera have been indexed by previous investigators and we plan on making use of this information in defining future research direction. The biology of crabs has been the subject of much research focused on Callinectes amnicola (Rochebrune, 1883) species. C. amnicola is an omnivorous species whose males are known to mature between 63 and $105 \mathrm{~mm}$ shell width, while females mature between 83.5 and $116.2 \mathrm{~mm}$ shell width. Fertility varies from 0.47 to 4.8 million eggs per female. However, exploitation parameters for this species in various lagoons are not available. A research direction geared towards establishing a new and thorough inventory along with currently nonexistent but relevant exploitation parameters will go a long way in defining sustainable management measures for these crab species.
\end{abstract}

(C) 2018 International Formulae Group. All rights reserved.

Keywords: Lagoon crabs, diversity, biology and exploitation, West Africa.

\section{INTRODUCTION}

Lagoons and estuaries are considered throughout the world as the most productive aquatic ecosystems (Lalèyè et al., 2007). In the West African tropical region, a succession of lagoons, lakes and estuaries run along the coast (Hardman-Mountford and McGlade, 2002; Lalèyè et al., 2007; Carpenter and De Angelis, 2014). Along the Gulf of Guinea, between Côte d'Ivoire and Nigeria, these ecosystems cover about $3,000 \mathrm{Km}^{2}$, with highly diversified living resources that are intensely exploited by a human population of a variety of backgrounds (Lalèyè et al., 2007). This exploitation focuses mostly on fish and crustaceans (Penaeid shrimps and Portunid crabs). Crabs, on the other hand, are a major component of lagoon fauna (Le Loeuf and Intès, 1968; Fischer et al., 1981), represent an important food resource for humans, and are the subject of a remarkable economic activity (Thiam and Diallo, 2010). Worldwide, total crab catches were estimated at 1.2 million tons in 2003 (Thiam and Diallo, 2010). 
However, it should be emphasized that since crabs are coastal creatures that are quite easy to catch, this figure is exclusive of individual and small-scale catching; especially in developing countries where they constitute are a cheap source of protein (Thiam and Diallo, 2010). Compared with fish and shrimps, however, scientific investigation on crabs as opposed to other fisheries groups such as fish and shrimp is lacking (Udoh and Nlewadim, 2011; Sara et al., 2010). In fact, of the identified publications covering research on crabs in West Africa, the first ones date back to the 1960s, although the last one was published in 2017. Of the earlier ones, the very first two are Monod (1956) and Manning \& Holtuis (1981) who established the first inventory of the entire marine, lagoon, and land crabs on the West African coast. Literature review on the exploitation and production of Callinectes sp. and Cardisoma sp. in West Africa (d'Almeida and Fiogbé, 2008) indicates an insufficient body of knowledge about these two species despite their socio-economic relevance. The authors have suggested that knowledge be improved relative to the estimation and exploitation of stocks as well as to the biological understanding necessary for a successful breeding of Callinectes amnicola (Rochebrune, 1883) and Cardisoma armatum (Herklots, 1851). Considering the full breadth of diversity in crab species in West African lagoons (Monod, 1956; Manning and Holthius, 1981) and in view of the scientific knowledge produced on this zoological group so far (Akin-Oriola et al., 2005; d'Almeida et al., 2006; Arimoro and Idoro, 2007; d'Almeida et al., 2007; d'Almeida et al., 2008; d'Almeida et al., 2009; George et al., 2009; George and Abowei, 2009; d'Almeida et al., 2009; d'Almeida et al., 2010; Udoh and Nlewadim, 2011; Omuvwie and Atobatele, 2013; Olakolu and Fakayode, 2014; Sankare et al., 2014 a; Onyekachi and Edah, 2014; d'Almeida et al., 2014), it appears necessary to have a review in order to establish what the current understanding on this group of crustacean is. We review known lagoon crab species in the Gulf of Guinea, their biology, and exploitation in order to identify relevant research prospects for this zoological group.

To attend this objective, publications touching on lagoon crabs in West Africa were identified using Google Scholar, Scopus, and Agris databases as well as UAC (University of Abomey-Calavi) and the Benin Ministry of Agriculture, Livestock, and Fisheries libraries. Publications search was conducted using the keywords crabe lagunaire, Afrique de l'Ouest (French) or lagoon crab, West Africa (English) (Assogbadjo et al., 2011; Wiegleb, 2016; Gangbè et al., 2016; Pochet, 2017). Database of crustacean catalogs of the France National Museum for Natural History, of the US National Museum of Natural History, and of the Leiden Natural Museum were also used. A list of crab species was established using species nomenclature as defined by $\mathrm{Ng}$ et al. (2008) as well as the recent systematic revised versions (Shahdadi and Schubart, 2017).

The present synthesis of current scientific knowledge on brackish water crabs in West Africa focuses on species encountered in Benin, Ghana, Côte d'Ivoire, Nigeria, and Togo (Figure 1). This review is made as a prelude to establishing an inventory and framing future research aimed at a promising exploitation of these species in Benin.

\section{LAGOON CRABS DIVERSITY IN THE GULF OF GUINEA}

Thirty-two crab species are reported in lagoons and associated mangrove habitats from Côte d'Ivoire to Nigeria. These species are divided into twenty-three genera and thirteen families (Table 1).

According to available literature, the highest species richness of lagoon crabs is observed in Nigeria (twenty-three species) and the lowest is observed in Togo (two species). Country size as well as the lagoons selected for developing the inventory justifies the observed gap. Regional surveys conducted during colonial times and around the period of the independence movement in West Africa have not included all the lagoons in such countries as Benin or Côte d'Ivoire. In Benin, no crab species have been reported in the 
coastal lagoon, in the Porto-Novo Lagoon, nor in Ahémé lake. This situation equally applies to the Grand Lahou and Aby lagoons in Côte d'Ivoire, as well. Subsequent surveys carried out in Benin, Nigeria, and Côte d'Ivoire revealed that twelve species were not reported in the first regional surveys, namely: Callinectes sapidus, Callinectes danae, Callinectes marginatus, Geryon maritae, Gecarcinus weileri, Portunus validus, Menippe nodifrons, Pilumnopeus caparti, Ocypoda cursor, Grapsus grapus, Pachygrapsus transversus, Cyclograpsus integrer. Unlike regional surveys, it is not possible to have access to the collections of national surveys because the authors have not specified the places where reported specimens are kept. New surveys on lagoon crabs are needed. Possibilities of molecular tests could be envisaged. Indeed, recent taxonomic overhauling has affected species of the Perisesarma genus in the West African carcinological fauna (Shadadi and Schubart, 2017). Assessing biodiversity according to UICN criteria would also be useful in the face of anthropogenic pressures on natural resources in general and on fisheries resources particularly. Edible species, which are economically important, are more the focus of biological and ecological investigations.

\section{LAGOON CRABS BIOLOGY IN THE GULF OF GUINEA}

Available information on the biological aspects of lagoon crabs covers more than $75 \%$ of the crab population encountered in Nigerian lagoons (Qua Iboe, Okpoka, Ojo, and Lagos lagoons), in Côte d'Ivoire lagoons (Ebrié, Aby, Grand Lahou and Fresco lagoons), and in Ghanaian waters (Mukwe and Sakumo). This information focuses mainly on Callinectes amnicola (Rochebrune, 1883), an abundant and economically-important species. Other scarcely-studied species include Callinectes pallidus (Rochebrune, 1883), Cardisoma armatum (Herklots, 1851) and Guinearma huzardi (Desmarest, 1825).

\section{Callinectes amnicola (Rochebrune, 1883)}

Callinectes amnicola has an omnivorous diet that varies with crab size
(Sankaré, 2007; George et al., 2009; Santhanam, 2018). The diet consists of oligochaetes, polychaetes, pelecypod molluscs, crustaceans, and aquatic insects (Sankaré, 2007) in Côte d'Ivoire waters. Specimens smaller than $5 \mathrm{~cm}$ in size tend to have a scavenger-type diet, while those whose size is between 5 and $10 \mathrm{~cm}$ are carnivorous (Sankaré, 2007). In the Lagos lagoon (Nigeria), diet is composed of lobsters, fish, mollusks, and crabs (Onyekachi and Edah, 2014). Maintaining the focus on Nigeria, diet in the Okpoka River is composed of crustaceans, fish, mollusks, annelids, algae, sand particles, and crab parts (George and Abowei, 2009).

Reproduction in Portunidae crabs occurs through mating. Crabs capable of swimming have a sexual dimorphism that is already detectable in post-larval stages (Bourgeois-Lebel, 1980; Charles Dominique et Hem, 1981; Sankaré, 2007; Arimoro and Idoro, 2007; Jivoff et al., 2007). C. amnicola reproduction in Ebrié Lagoon (Côte d'Ivoire) is characterized by female migration from desalinated zones to the meso-euhaline areas near Vridi channel. This migration is followed by gonad maturation. Males are much more sedentary and are found in oligohaline waters, sometimes in fresh waters (Charles Dominique and Hem, 1981). Studies describing differentiation in $C$. amnicola reproduction organs, with scales of sexual maturity, have been carried out (Charles Dominique and Hem, 1981; d' Almeida et al., 2006; d' Almeida et al., 2007; Sankaré, 2007; d' Almeida et al., 2008; d' Almeida et al., 2009; d' Almeida et al., 2010; d' Almeida et al., 2014). These sexual maturity scales display 7 stages. Table 2 shows size at first sexual maturity for the identified species in some of the lagoons in the study area. The biological cycle of the species described by Lhomme (1994) is presented on Figure 2.

\section{Callinectes pallidus (Rochebrune, 1883)}

Callinectes pallidus biological cycle occurs in both seawater and lagoon (Lhomme, 1994). Indeed, C. pallidus is a coastal marine species that penetrates mesohaline brackish 
waters (Monod, 1956; Williams, 1974; Manning and Holthuis, 1981). Its diet was studied in the Ojo Estuary in Badagri, Nigeria. It consists of fish, molluscs, crustaceans, macroscopic plants, algae, sand particles, and unidentified masses (Jimoh et al., 2014; Santhaman, 2018). Males consume more fish while females consume more plants. No reproduction parameters of this species are available.

\section{Cardisoma armatum Herklots, 1851}

Studies on Cardisoma armatum have focused on its ecoethological parameters, diet, and reproduction. This species colonizes more clay soils, has a mainly phytophagous diet, and feeds mainly on Paspalum vaginatum leaves, palm nuts (Elaeis guineensis), and coconut (Cocos nucifera) (Hounga, 1999). It has an active phase on the land surface at night and an apparent resting phase in burrows in the daytime (Mensah and Gbeto, 2001). Akin-Oriola et al. (2005) have investigated the morphometric, meristic, and growth parameters in $C$. armatum compared with those of $C$. pallidus. Morphometric and meristic parameters and weight-length relationship in $C$. armatum were also compared with those in the $C$. amnicola swimming blue crab in the Nokoué Lake/Porto-Novo Lagoon complex of Benin (Goussanou et al., 2017a). Embryonic development in $C$. armatum has also been described (d'Almeida et al., 2014). It appears that its embryonic development involves a transformation process of a telolecith egg into larva. Fertilized eggs exude from the cavity of gravid or grainy females through gonopores and attach to the bristles of biramous pleopods. These females become ovigerous in the abdomen where embryogenesis takes place and involves the stages of segmentation, gastrulation, and organogenesis. Macroscopically, fertilized eggs and germs shape a cluster whose color changes from orange to yellow, to gray, and finally to black. At the end of this process, the embryos are released into the aquatic environment to undergo actual larval development which, after metamorphosis, will give a juvenile crab that comes out of the lagoon environment to live its life on earth. This explanation supports the occasional arrival of $C$. armatum into lagoon waters (Akin-Oriola et al., 2005). It, however, has to be noted that the $C$. armatum sexual maturity scale, its breeding season, and its first maturity size in various environments in the sub-region are still unknown and are part of the questions future research should address.

\section{Guinearma huzardi (Desmarest, 1825)}

The diet of this species consists of mangrove leaves, fish, and other crabs (Lawal-Are and Nwankwo, 2011). The same authors have observed a sex ratio in favor of males. Fertility ranges from 1.5 to 3.5 million eggs with egg diameter ranging from 0.21 to $0.33 \mathrm{~mm}$.

Two species have mainly been the focus of biology-related investigations: Callinectes amnicola and Cardisoma armatum. Knowledge gained from the biology and ecology of Callinectes amnicola is an essential basis for the establishment of sustainable management measures based on biological indicators. Future diet-related investigations focusing on daily dietary habits and an estimation of dietary requirements will be useful to feeding efficiency within the framework of farming this species. As for reproduction parameters, knowledge of the size at first maturity as well as the breeding season and preferred breeding grounds on each lagoon are essential for the sustainable management of crabs.

Regarding Callinectes pallidus, the total lack of information on the reproduction of the species will have to be filled in order to understand its life cycle and to assess its exploitation rate in the lagoons of the Gulf of Guinea.

As far is Cardisoma armatum is concerned, existing work makes it possible to understand that its life cycle occurs on the earth with an occasional introduction in lagoon waters, just as swimming crabs do (Akin-Oriola et al., 2005). The scale of maturity applicable to the species, its breeding season, and the size at first maturity in the various West African environments are yet to be established. Available information on its 
biological life does not, as yet, allow making a statement on the extent of its exploitation.

\section{EXPLOITATION OF LAGOON CRABS IN THE GULF OF GUINEA}

Available knowledge relating to the exploitation of lagoon crabs covers primarily the Callinectes amnicola species in a few countries. As well, exploitation statistics do not cover that much of a continuous timespan and are derived from short-term investigations. Compiled data is shown in Table 3.

In Côte d'Ivoire lagoons, most Callinectes amnicola fishing is done by gillnets. This gear has a potential danger for the maintenance of the fertility of the stock, since catches are generally made before breeding, and fishing pressure seems very high (Charles Dominique and Hem, 1981, Lhomme, 1994). On the Ebrié lagoon, Charles Dominique and Hem (1981) have reported the following select crab fishing gear: gillnets; crab trap, and multiply-hooked lines. On the other hand, the poorly selective gear which captures almost all size classes include gillnets, seines, and purse seines.

From 2006 to 2009, average catch per unit effort was $33 \mathrm{~kg} / \mathrm{landing}$ for the Fresco Lagoon, 16.5 to $32.25 \mathrm{~kg} /$ landing for the Grand-Lahou Lagoon, from 25 to 38.5 $\mathrm{kg} / \mathrm{landing}$ for the Ebrié Lagoon and from 5 to $88.25 \mathrm{~kg} / \mathrm{landing}$ for the Aby Lagoon (Sankaré et al., 2014a).

In the Lagos Lagoon of Nigeria, circular lift net and wire basket traps are fishing gears inventoried (Babatunde, 2008). The catch per unit effort varies from 2.5 to 15 crabs for circular lift net (very selective gear) as opposed to 5.6 to 17 crabs for wire basket trap. In Benin, crab fishermen are estimated to number roughly 2030, including 588 women (Gnimadi et al., 2008).

The socio-economic importance of Callinectes amnicola in West African lagoons (Le Loeuf and Intes, 1968, Gnimadi et al., 2008, d'Almeida and Fiogbé, 2008) justifies the fact that the available exploitation information is relevant only to this species. Crab catches have generally doubled in
Beninese lagoons between 2000 and 2008 . This increase is also observed in Ivorian lagoons with the exception of the Aby Lagoon where catches have decreased (Sankaré et al., 2014a). The decrease in catches in the Aby Lagoon is related to the increase in the number of fishermen, fishing gear, the catching of females, and the closure of the lagoon's natural channel (Sankaré et al., 2014b). From Côte d'Ivoire to Nigeria, exploitation parameters have not been evaluated. However, this information is available on other economically-important Portunid crabs such as Portunus pelagicus and Portunus sanguinolentus elsewhere in the world (Muller et al., 2006; Dash et al., 2013; Chutapa et al., 2014). Dash et al. (2013) report an exploitation rate of $\mathrm{E}=0.61$ for Portunus sanguinolentus in India between 2009 and 2010. In Thailand, Chutapa et al. (2014) have reported an exploitation rate of $\mathrm{E}=0.71$ for Portunus pelagicus between 2008 and 2009. Analyzes are made by these authors, which gave recommendations for sustainable management of crab fisheries. The FiSAT II software (Sparre \& Venema, 1998) which uses the size frequencies to generate the population and exploitation parameters is used. Considering the strong fishing pressures reported on the Callinectes amnicola species in West African lagoon environments (Charles Dominique and Hem, 1981; Lhomme, 1994; Gnimadi et al., 2008; d'Almeida and Fiogbé, 2008; Sankaré, 2007; Sankaré et al., 2014a; Sankaré et al., 2014b), it is highly recommended to evaluate the exploitation parameters of the Callinectes amnicola species in the various lagoon ecosystems in the Golf of Guinea. The socio-economic importance of crab fisheries also deserves to be studied. As for the Cardisoma armatum land crab, apart from catching by traps known in West African countries, catch statistics are not available.

\section{FARMING LAGOON CRABS IN THE GULF OF GUINEA}

Callinectes amnicola farming trials have been tested and show that it can be done in drainable ponds (Sohou et al., 2016; 
Goussanou et al., 2017b). Effective command of the control of the Scylla serrata brackish water crab farming, which belongs to the same family as Callinectes amnicola (Mirera, 2014; Davis, 2004), can serve as a basis for further domestication studies. With regard to Cardiosoma armatum, the conditions of its rearing in pens have also been studied (Edéa et al., 2015). The rearing in pens (sandy substrate with fresh water) is still unsuccessful (Mensah and Gbeto, 2001; Edea et al., 2015). The artificial reproduction of the species and larval development are described by Cuesta and Anger (2005) in an aquarium. A salinity of $25 \%$ allows the best survival of eggs and larvae through metamorphosis. Subsequent trials should take into account this optimum salinity value for crab farming purposes.

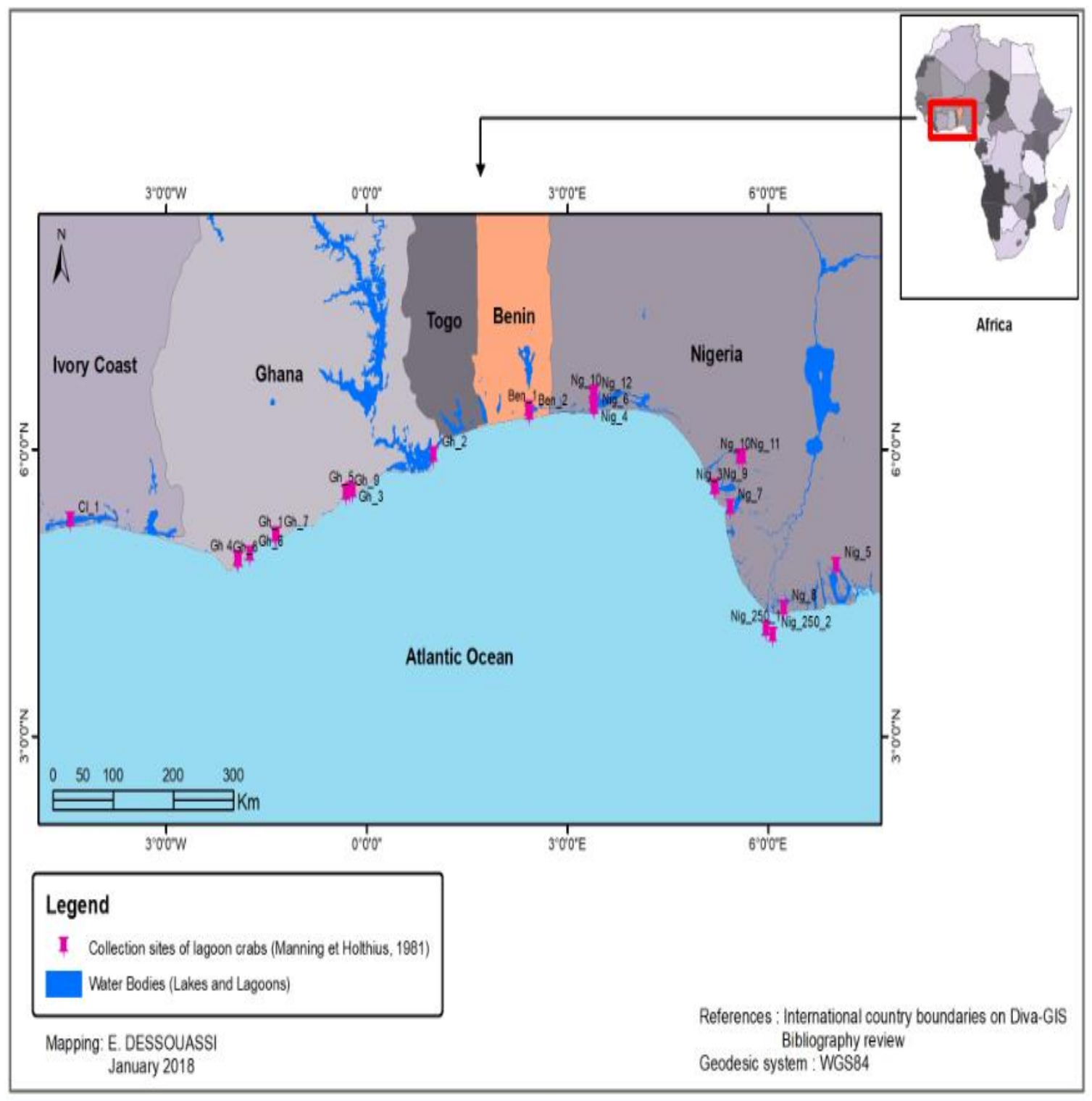

Figure 1: Geographical area covered by the review. 
Table 1: List of crab species identified in the lagoons of five countries on the Gulf of Guinea.

\begin{tabular}{|c|c|c|c|}
\hline Family/Species & Country & $\begin{array}{c}\text { Museums/ } \\
\text { Register Number }\end{array}$ & References \\
\hline \multicolumn{4}{|l|}{ Dromiidae } \\
\hline $\begin{array}{l}\text { Sternodromia monodi (Forest \& Guinot, } \\
\text { 1966) }\end{array}$ & Nigeria & $\begin{array}{l}\text { RMNH.CRUS.D. } 27151 \\
\text { RMNH.CRUS.D. } 27152\end{array}$ & Manning and Holthuis (1981) \\
\hline \multicolumn{4}{|l|}{ Dorippidae } \\
\hline Phyllodorippe armata (Miers, 1881). & Nigeria & RMNH.CRUS.D.23325 & Manning and Holthuis (1981) \\
\hline \multicolumn{4}{|l|}{ Menippidae } \\
\hline \multirow[t]{2}{*}{ Menippe nodifrons Stimpson, 1859} & $\begin{array}{l}\text { Côte } \\
\text { d'Ivoire }\end{array}$ & N/A & Sankaré (2005) \\
\hline & Benin & N/A & Hountogan (2012) \\
\hline
\end{tabular}

\section{Euryplacidae}

\begin{tabular}{llll}
\hline Machaerus oxyacanthus (Monod, 1956) & Nigeria & RMNH.CRUS.D.44442 & Manning and Holthuis (1981) \\
\hline Parthenopidae & & & \\
\hline Parthenopoides massena (Roux, 1830) & \multirow{2}{*}{ Nigeria } & $\begin{array}{l}\text { RMNH.CRUS.D.24025 } \\
\text { RMNH.CRUS.D.24026 }\end{array}$ & Manning and Holthuis (1981) \\
\hline
\end{tabular}

\section{Pilumnidae}

\begin{tabular}{llcc}
\hline & Nigeria & RMNH.CRUS.D.23664 & Manning and Holthuis (1981) \\
\cline { 2 - 4 } Pilumnopeus africanus (De Man, 1902) & Nigeria & USMN 170334 & https://collection.nmnh.si.edu/ \\
\cline { 2 - 4 } & $\begin{array}{l}\text { Côte } \\
\text { d'Ivoire }\end{array}$ & USNM & Manning and Holthuis (1981) \\
\cline { 2 - 4 } & Benin & $\begin{array}{l}\text { RMNH.CRUS.D.19944- } \\
\text { RMNH.CRUS.D.19946 }\end{array}$ & Manning and Holthuis (1981) \\
\hline Pilumnopeus caparti (Monod, 1956) & $\begin{array}{l}\text { Côte } \\
\text { d'Ivoire }\end{array}$ & N/A & Sankaré (2005) \\
& & & \\
\hline
\end{tabular}

\section{Portunidae}

Callinectes amnicola (Rochebrune, 1883)

\begin{tabular}{lcc} 
Ghana & RMNH.CRUS.D.58 & Manning and Holthuis (1981) \\
\hline Ghana & USNM 170116-170118 & https://collection.nmnh.si.edu/ \\
\hline Togo & USNM 143985 & $\begin{array}{l}\text { Manning and Holthuis (1981) } \\
\text { https://collection.nmnh.si.edu/ }\end{array}$ \\
\hline Nigeria & USNM 120943 & $\begin{array}{l}\text { Manning and Holthuis (1981) } \\
\text { https://collection.nmnh.si.edu/ }\end{array}$ \\
\hline $\begin{array}{l}\text { Côte } \\
\text { d'Ivoire }\end{array}$ & N/A & Sankaré (2005) \\
\hline
\end{tabular}

\begin{tabular}{lcc}
\hline & & Murai et al. (2003); \\
Adandédjan (2012); & Hountogan (2012); \\
& N/A & $\begin{array}{c}\text { Dessouassi (2014), Mensah } \\
(2014)\end{array}$ \\
\hline Nigeria & RMNH.CRUS. D.15533 & $\begin{array}{c}\text { Manning and Holthuis (1981); } \\
\text { http://bioportal.naturalis.nl }\end{array}$ \\
\hline
\end{tabular}




\section{http://bioportal.naturalis.nl/ \\ Nigeria RMNH.CRUS.D.15532 (Manning and Holthuis \\ (1981); Amadi(1990); Akin- \\ Oriola et al.(2005)}

Callinectes pallidus (Rochebrune, 1883)

\begin{tabular}{lcc}
\hline Ghana & USNM 14879 & $\begin{array}{c}\text { Manning and Holthuis (1981) } \\
\text { https://collection.nmnh.si.edu/ }\end{array}$ \\
\hline $\begin{array}{l}\text { Côte } \\
\text { d'Ivoire }\end{array}$ & N/A & Sankaré (2005) \\
\hline Benin & N/A & Aka et al. (1999) \\
\hline Nigeria & N/A & $\begin{array}{c}\text { Amadi (1990) ; Akin-Oriola } \\
\text { et al. (2005) }\end{array}$ \\
\hline $\begin{array}{l}\text { Côte } \\
\text { d'Ivoire }\end{array}$ & N/A & Sankaré (2005) \\
\hline Benin & N/A & Adandédjan (2012) \\
Benin & N/A & Adandédjan (2012) \\
Benin & N/A & Murai et al. (2003)
\end{tabular}

Callinectes marginatus (A. Milne-
Edwards, 1861)

RMNH.CRUS.D.24575- Monod (1956) ; Manning and

Callinectes marginatus (A. Milne-
Edwards, 1861)

24577

Holthuis (1981)

RMNH.CRUS.D.25287

Panopeidae

\begin{tabular}{llcc}
\hline \multirow{2}{*}{$\begin{array}{l}\text { Panopeus africanus A. Milne-Edwards, } \\
1867\end{array}$} & Nigeria & RMNH.CRUS.D.15548 & $\frac{\text { http://bioportal.naturalis.nl/; }}{\text { Monod (1956) }}$ \\
\cline { 2 - 4 } & $\begin{array}{l}\text { Côte } \\
\text { d'Ivoire }\end{array}$ & N/A & Sankaré (2005) \\
\cline { 2 - 4 } & Benin & RMNH.CRUS.D.18735 & Manning and Holthuis (1981) \\
\hline Xanthidae & & & Manning and Holthuis (1981) \\
$\begin{array}{l}\text { Nanocassiope melanodactylus (A. } \\
\text { Milne- Edwards, 1867) }\end{array}$ & Nigeria & USNM & \\
\hline
\end{tabular}

\section{Gecarcinidae}

\begin{tabular}{|c|c|c|c|}
\hline \multirow{6}{*}{ Cardisoma armatum Herklots, 1851} & $\begin{array}{l}\text { Côte } \\
\text { d'Ivoire }\end{array}$ & N/A & Monod (1956) \\
\hline & Ghana & RMNH.CRUS.D.58 & Manning and Holthuis (1981). \\
\hline & Ghana & MNHN 2403 & Monod (1956) \\
\hline & Togo & N/A & Monod (1956) \\
\hline & Benin & RMNH.CRUS.D.17890 & $\begin{array}{l}\text { Manning and Holthuis (1981) } \\
\text {; Adandédjan (2012) }\end{array}$ \\
\hline & Nigeria & RMNH.CRUS.D.15472 & Manning and Holthuis (1981) \\
\hline Johngarthia weileri (Slendler, 1912) & Nigeria & N/A & $\begin{array}{c}\text { Amadi (1990) ; Akin-Oriola } \\
\text { et al. (2005) }\end{array}$ \\
\hline \multicolumn{4}{|l|}{ Grapsidae } \\
\hline \multirow{3}{*}{ Goniopsis pelii (Herklots, 1851) } & Ghana & RMNH.CRUS.D.68 & Manning and Holthuis (1981 \\
\hline & Nigeria & RMNH.CRUS. D.15518 & $\begin{array}{l}\text { Manning and Holthuis (1981); } \\
\text { http://bioportal.naturalis.nl }\end{array}$ \\
\hline & Benin & N/A & Hountogan (2012) \\
\hline
\end{tabular}




\begin{tabular}{|c|c|c|c|}
\hline & $\begin{array}{l}\text { Côte } \\
\text { d'Ivoire }\end{array}$ & N/A & $\begin{array}{c}\text { Monod (1956) ; Manning and } \\
\text { Holthuis (1981) }\end{array}$ \\
\hline \multirow{4}{*}{ Pachygrapsus gracilis (Saussure, 1858) } & Nigeria & RMNH.CRUS. D.15553 & $\begin{array}{l}\text { Manning and Holthuis (1981); } \\
\text { http://bioportal.naturalis.nl }\end{array}$ \\
\hline & Ghana & USNM 170340 & Manning and Holthuis (1981) \\
\hline & Benin & RMNH.CRUS.D.19935 & Manning and Holthuis (1981) \\
\hline & $\begin{array}{l}\text { Côte } \\
\text { d'Ivoire }\end{array}$ & N/A & Sankaré (2005) \\
\hline $\begin{array}{l}\text { Pachygrapsus transversus (Gibbes, } \\
\text { 1850) }\end{array}$ & $\begin{array}{l}\text { Côte } \\
\text { d'Ivoire }\end{array}$ & N/A & Sankaré (2005) \\
\hline Grapsus grapsus (Linneaus, 1758) & $\begin{array}{l}\text { Côte } \\
\text { d'Ivoire }\end{array}$ & N/A & Sankaré (2005) \\
\hline $\begin{array}{l}\text { Cyclograpus integer H. Milne Edwards, } \\
1837\end{array}$ & $\begin{array}{l}\text { Côte } \\
\text { d'Ivoire }\end{array}$ & N/A & Sankaré (2005) \\
\hline \multicolumn{4}{|l|}{ Sesarmidae } \\
\hline \multirow{5}{*}{$\begin{array}{l}\text { Metagrapsus curvatus (H. Milne } \\
\text { Edwards, 1837) }\end{array}$} & & RMNH.CRUS.D.31013 & Manning and Holthuis (1981); \\
\hline & Nigeria & $\begin{array}{l}\text { RMNH.CRUS.D. } 30887 \\
\text { RMNH.CRUS. D. } 15537\end{array}$ & $\begin{array}{l}\text { Shahdadi and Schubart (2017) } \\
\text { http://bioportal.naturalis.nl }\end{array}$ \\
\hline & $\begin{array}{l}\text { Côte } \\
\text { d'Ivoire }\end{array}$ & N/A & Sankaré (2005) \\
\hline & Benin & N/A & Adandédjan (2012) \\
\hline & Ghana & RMNH.CRUS. D.182 & Manning and Holthuis (1981). \\
\hline \multirow{4}{*}{$\begin{array}{l}\text { Chiromantes(Sesarma)angolense De } \\
\text { Brito Capello, } 1864\end{array}$} & Nigeria & RMNH.CRUS. D.15538 & http://bioportal.naturalis.nl \\
\hline & Ghana & MNHN 2398 & Monod (1956) \\
\hline & Benin & N/A & Hountogan (2012) \\
\hline & $\begin{array}{l}\text { Côte } \\
\text { d'Ivoire }\end{array}$ & N/A & Monod (1956) \\
\hline \multirow[b]{2}{*}{$\begin{array}{l}\text { Chiromantes (Sesarma) buettikoferi De } \\
\text { Man, } 1883\end{array}$} & Nigeria & RMNH.CRUS.D.30988 & Manning and Holthuis (1981) \\
\hline & $\begin{array}{l}\text { Côte } \\
\text { d'Ivoire }\end{array}$ & RMNH.CRUS.D.19862 & Manning and Holthuis (1981) \\
\hline \multirow{4}{*}{ Armases elegans (Herklots, 1851) } & Ghana & $\begin{array}{l}\text { RMNH.CRUS. D.150- } \\
151\end{array}$ & Monod (1956) \\
\hline & $\begin{array}{l}\text { Côte } \\
\text { d'Ivoire }\end{array}$ & N/A & Sankaré (2005) \\
\hline & Benin & N/A & Adandédjan (2012) \\
\hline & Nigeria & RMNH.CRUS. D.15567 & $\begin{array}{l}\text { Manning and Holthuis (1981) } \\
\text { ¿http://bioportal.naturalis.nl }\end{array}$ \\
\hline \multirow{2}{*}{ Guinearma alberti (Rathbun, 1921) } & Nigeria & RMNH.CRUS. D.15536 & $\frac{\text { Manning and Holthuis (1981) }}{\text { ¡http://bioportal.naturalis.nl }}$ \\
\hline & $\begin{array}{l}\text { Côte } \\
\text { d'Ivoire }\end{array}$ & N/A & Monod (1956) \\
\hline \multirow{2}{*}{ Guinearma huzardi (Desmarest, 1825) } & $\begin{array}{l}\text { Côte } \\
\text { d'Ivoire }\end{array}$ & RMNH.CRUS.D.19849 & Manning and Holthuis (1981) \\
\hline & Benin & RMNH.CRUS.D.18729 & $\begin{array}{l}\text { Manning and Holthuis (1981) } \\
\text {; Adandédjan (2012) }\end{array}$ \\
\hline
\end{tabular}




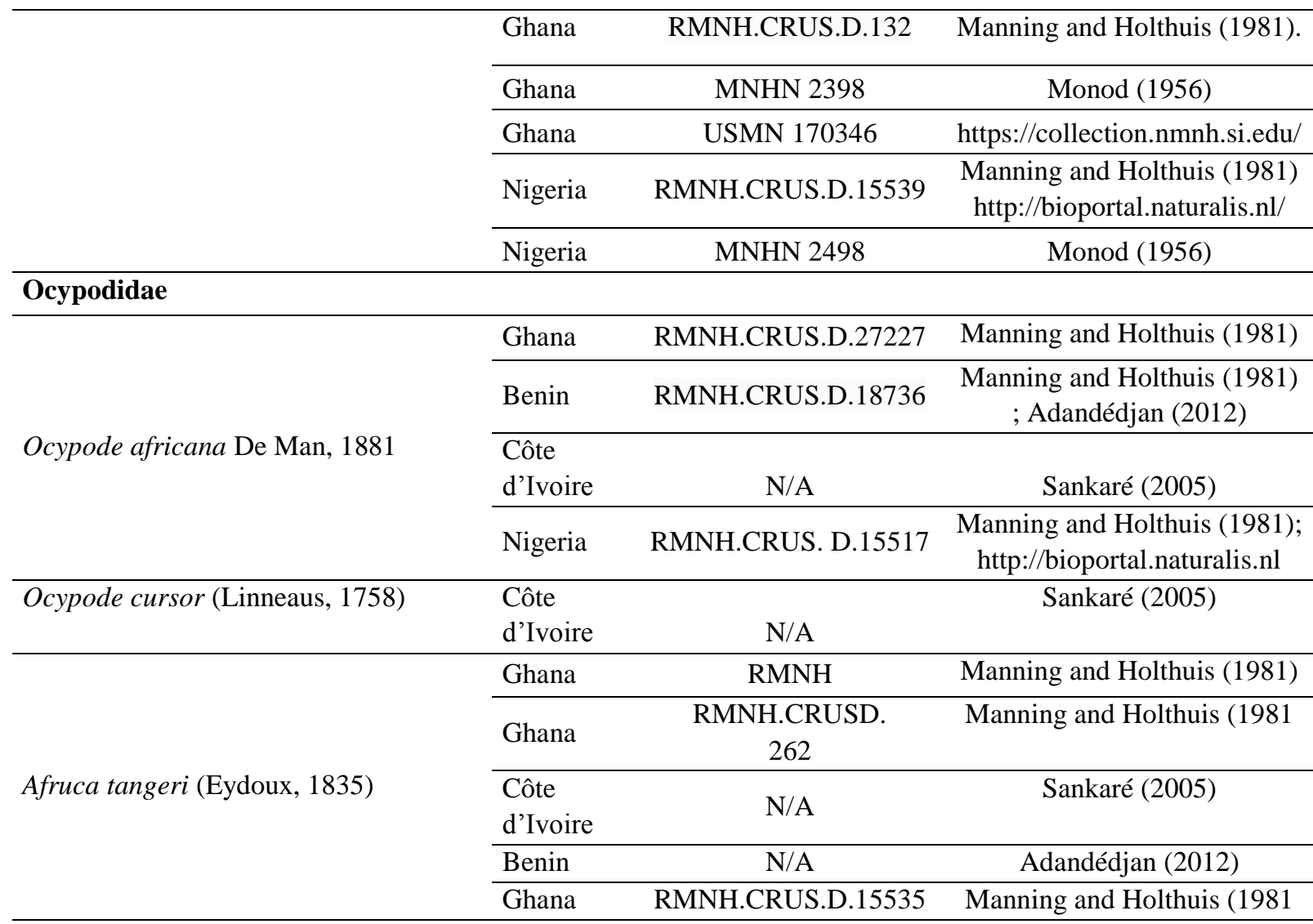

MNHN: French National Museum for Natural History (Paris), USMN: US National Museum of Natural History; RMNH:

Leiden Naturalis Museum; NA: museum/register number not available.

Table 2: Size at first sexual maturity in Callinectes amnicola in the lagoons of the Gulf of Guinea.

\begin{tabular}{|c|c|c|c|c|c|c|}
\hline \multirow[t]{2}{*}{ No } & \multicolumn{2}{|c|}{$\begin{array}{l}\text { First maturity size } \\
(\mathrm{cm})\end{array}$} & \multirow[t]{2}{*}{$\begin{array}{c}\text { Reproductive } \\
\text { period }\end{array}$} & \multirow[t]{2}{*}{$\begin{array}{c}\text { Females fertility } \\
\text { (million eggs per crab) }\end{array}$} & \multirow[t]{2}{*}{ Area } & \multirow[t]{2}{*}{ References } \\
\hline & Male & Female & & & & \\
\hline 1 & 8 & 9 & $\begin{array}{l}\text { March-April } \\
\text { and August }\end{array}$ & $0.5-2$ & $\begin{array}{l}\text { Côte d'Ivoire: } \\
\text { Aby-Tendo-Ehy } \\
\text { lagoon complex }\end{array}$ & $\begin{array}{c}\text { Sankaré } \\
(2007)\end{array}$ \\
\hline 2 & 6.3 & 8.35 & N/A & $\begin{array}{c}1.902 \pm 0.24 \text { to } 2.82 \pm \\
0.32\end{array}$ & $\begin{array}{l}\text { Ghana: Mukwe } \\
\text { and Sakumo }\end{array}$ & Kwei (1978) \\
\hline 3 & 9.16 & 11.62 & N/A & N/A & $\begin{array}{l}\text { Benin : } \\
\text { Ahémé lake }\end{array}$ & $\begin{array}{l}\text { Dessouassi } \\
(2014)\end{array}$ \\
\hline 4 & 10.5 & 11.0 & N/A & $0.47-4.48$ & $\begin{array}{l}\text { Nigeria : Lagos } \\
\text { lagoon }\end{array}$ & $\begin{array}{l}\text { Santhanam } \\
\text { (2018) }\end{array}$ \\
\hline
\end{tabular}

N/A: Not available. 


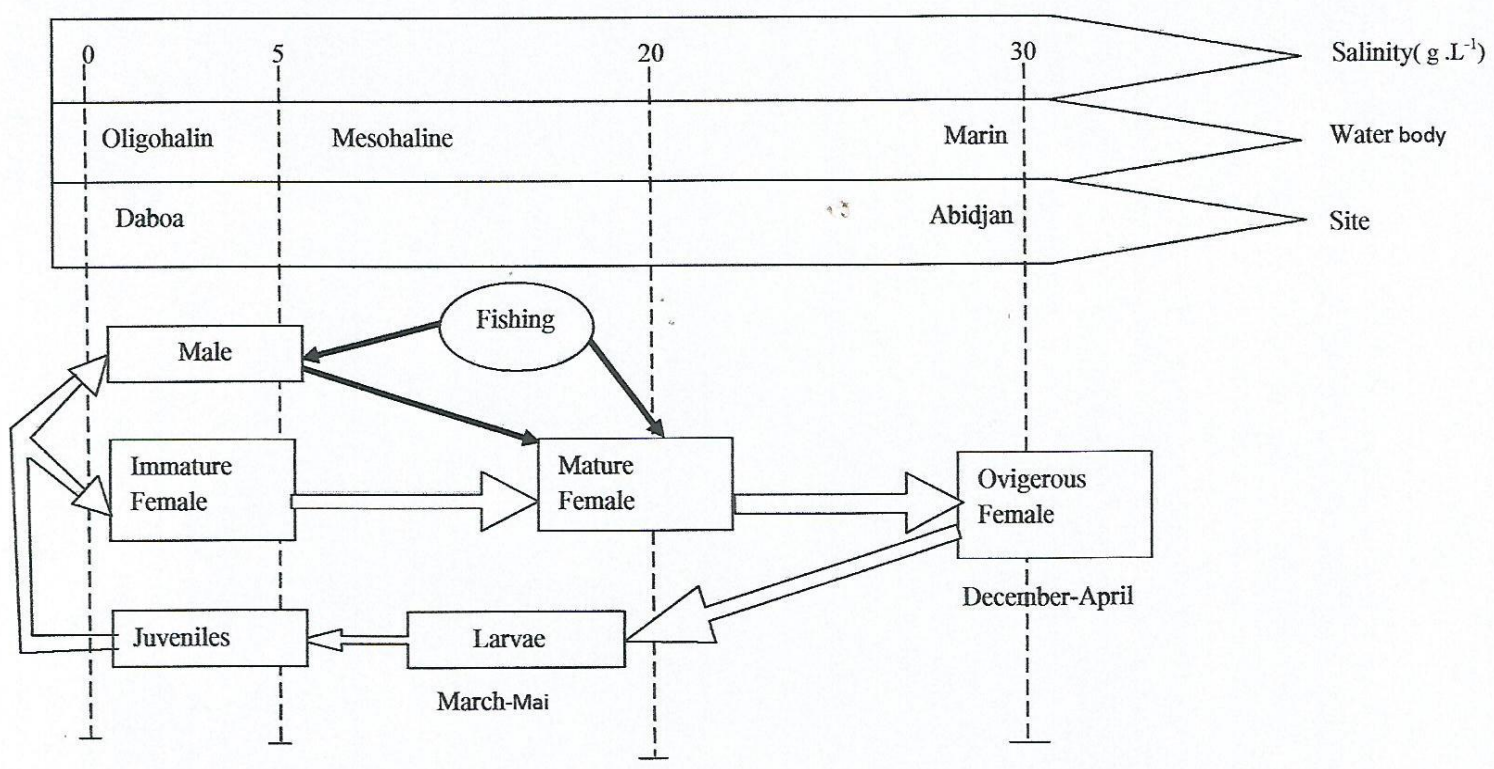

Figure 2: Biological cycle of Callinectes amnicola in Ebrié lagoon, Côte d'Ivoire (Lhomme, 1994).

Table 3 : Catch data of Callinectes amnicola crabs in a few lagoons in the Gulf of Guinea.

\begin{tabular}{|c|c|c|c|c|}
\hline Country & Water body & $\begin{array}{l}\text { Reference } \\
\text { years }\end{array}$ & $\begin{array}{c}\text { Annual } \\
\text { production (tons) }\end{array}$ & References \\
\hline \multirow{9}{*}{ Benin } & \multirow[b]{2}{*}{ Nokoué Lake } & $1990-2000$ & 2678.605 & D/Pêches (2001) \\
\hline & & 2016 & 828 & $\begin{array}{c}\text { DPH(2016); DPH(2017a); DPH } \\
\text { (2017b); DPH(2017c) }\end{array}$ \\
\hline & \multirow[b]{2}{*}{ Porto-Novo Lagoon } & $1990-2000$ & 342.28 & D/Pêches (2001) \\
\hline & & 2016 & 74.11 & $\begin{array}{c}\text { DPH(2016); DPH(2017a); DPH } \\
\text { (2017b); DPH(2017c) }\end{array}$ \\
\hline & $\begin{array}{l}\text { Nokoué Lake-Porto- } \\
\text { Novo Lagoon }\end{array}$ & 2008 & 5846.464 & Gnimadi et al. (2008) \\
\hline & \multirow[b]{2}{*}{ Ahémé Lake } & $1990-2000$ & 541.985 & D/Pêches (2001) \\
\hline & & 2016 & 79.85 & $\begin{array}{c}\text { DPH(2016); DPH(2017a); DPH } \\
\text { (2017b); DPH(2017c) }\end{array}$ \\
\hline & Coastal Lagoon & $1990-2000$ & 173.6238 & D/Pêches (2001) \\
\hline & $\begin{array}{l}\text { Ahémé Lake-Coastal } \\
\text { Lagoon }\end{array}$ & 2008 & 1379.016 & Gnimadi et al. (2008) \\
\hline \multirow{7}{*}{$\begin{array}{l}\text { Côte } \\
\text { d'Ivoire }\end{array}$} & \multirow[t]{2}{*}{ Aby Lagoon } & 2001 & 3747 & Sankaré (2007) \\
\hline & & 2006-2009 & 2720 & Sankaré et al. (2014a) \\
\hline & \multirow[t]{3}{*}{ Ebrié Lagoon } & 1975 & 190 & Charles Dominique and Hem (1981) \\
\hline & & 1979 & 825.2 & Charles Dominique and Hem (1981) \\
\hline & & $2006-2009$ & 2248 & Sankaré et al. (2014a) \\
\hline & Grand-Lahou Lagoon & $2006-2009$ & 823 & Sankaré et al. (2014a) \\
\hline & Fresco Lagoon & $2006-2009$ & 14.75 & Sankaré et al. (2014a) \\
\hline
\end{tabular}




\section{Conclusion}

The knowledge based on lagoon crabs is variable in Gulf of Guinea countries, namely from Côte d'Ivoire to Nigeria. West African surveys conducted in the 1960s provided information on diversity. This information has been supplemented in some countries (Côte d'Ivoire, Benin, and Nigeria) by national surveys.

Thirty-two species belonging to thirteen families and twenty genera are known in West African lagoon environments. The highest species richness was reported in Nigeria (23 species) and in Côte d'Ivoire (22 species). Seventeen species have been identified in Benin, 11 in Ghana, and 02 species in Togo. Callinectes amnicola breeding biology, diet, and growth have been studied in Côte d'Ivoire and Nigeria lagoons. However, the Callinectes amnicola breeding season, dietary habits, and growth have been studied in Ivorian and Nigerian lagoons. Breeding areas of this species are not yet known in most of West African lagoons. However, its size at first maturity, breeding season and best breeding grounds are not yet known in most of West African lagoons.

The estimation of exploitation parameters of this species which is intensely caught in different lagoons seems important for management measures.

It is also important to initiate research on the socio-economic importance of Callinectes amnicola caught in lagoons. Cardisoma armatum species has also been investigated in some biological surveys. The other thirty species are potential research subjects.

\section{COMPETING INTERESTS}

The authors declare that they have no competing interests.

\section{AUTHORS CONTRIBUTIONS}

CED collected the diversity data and wrote the manuscript. AC and LG collected the biology data. DA collected the exploitation data. DL and PL read and corrected the manuscript.

\section{ACKNOWLEDGEMENTS}

We would like to thank Professeur Danièle Guinot (MNHN) for Monod (1956) and advices provided; Karen Dorp Van (RMNH) for assistance in catalogue database search.

\section{REFERENCES}

Adandédjan D. 2012. Diversité et déterminisme des peuplements de macroinvertébrés benthiques de deux lagunes du Sud-Bénin : la Lagune de Porto-Novo et la Lagune Côtière. Thèse de Doctorat, Université d'AbomeyCalavi, Abomey-Calavi, p. 239.

Aka NAD, Allabi ACE, Dreyfuss G, KindeGazard D, Tawo L, Rondelaud D, Bouteille B, Avode G, Anagonou SY, Gninafon M, Massougbodji A, Dumas M. 1999. Observations épidémiologiques sur le premier cas de paragonimose humaine et les hôtes intermédiaires potentiels de Paragonimus sp. au Bénin. Manuscrit $n^{\circ}$ 2017. Bull. Soc. Pathol. Exot., 92:191-194.

Akin-Oriola G, Anetekhai M, Olowonirejuaro K. 2005. Morphometric and Meristic Studies in Two Crabs: Cardiosoma armatum and Callinectes pallidus. Turk J. Fish Aquat. Sc., 5: 85-89.

Amadi AA. 1990. A comparative ecology of estuaries in Nigeria. Hydrobiologia, 208(1): 27-38. $\quad$ DOI: 10.1007 /BF00008440

Arimoro FO, Idoro BO. 2007. Ecological Studies and Biology of Callinectes amnicola (Family: Portunidae) in the Lower of Reaches of Warri River, Delta State, Nigeria. WJZ., 2(2): 57-66.

Assogbadjo AE, Aihou K, Youssao IAK, Fovet-rabot C, Mensah GA. 2011. L'écriture scientifique au Bénin Guide contextualize de formation. Dépôt légal $\mathrm{n}^{\circ} 5372$ du 26 septembre 2011, $3^{\text {ème }}$ Trimestre 2011. Coco New Tech: Cotonou.

Babatunde EE. 2008. The fisheries and the Bionomics of swimming crab, Callinectes amnicola (De Rochebrune, 1883) from a tropical lagoon and its 
adjacent creek, southwest Nigeria. $J$. Fish Aquat. Sci., 3(2): 114-125.

Bourgeois-Lebel S. 1980. Contribution à la connaissance des Callinectes de la mangrove de Guadeloupe (Antilles française). Thèse de doctorat de $3^{\text {ème }}$ Cycle, Université Sciences et Technique de Languedoc, p.152.

Carpenter KE, De Angelis N. 2014. The Living Marine Resources of the Eastern Central Atlantic. FAO Species Identification Guide for Fishery Purposes. Foods and Agriculture Organization of the United Nations: Rome.

Charles Dominiques E, Hem S. 1981. Biologie et pêche des crabes du genre Callinectes stimpson, 1860 (Décapodes, Portunidae) en lagune Ebrié (cote d'Ivoire- résultats préliminaires. Doc. Sci. Centre Rech. Océanogr. Abidjan., 7(01): 95-121.

Chutapa K, Nantana G, Nittharatana P. 2014. A Stock Assessment of the Blue Swimming Crab Portunus pelagicus (Linnaeus, 1758) for Sustainable Management in Kung Krabaen Bay, Gulf of Thailand. Trop Life Sci Res., 25(1): 41-59.

Cuesta JA, Anger K. 2005. Larval morphology and salinity tolerance of a land crab from West Africa, Cardiosoma armatum (Brachyura: Grapsoidea: Gecarcinidae). J. Crust. Biol., 25(4): 640-654.

D’Almeida FMA, Fiogbé ED. 2008. Revue documentaire sur l'exploitation et la production des crabes (Callinectes et Cardiosoma). Rapport final de mission de consultation. Programme pour les Moyens d'Existence Durables dans la pêche, Cotonou.

D’Almeida M-A, Sankaré Y, Koua HK. 2006. Etude microscopique de l'ovogenèse chez la femelle de Callinectes amnicola (De rochebrune, 1883) (Décapoda Portuntdae). J. Rech. Sci. Univ. Lomé Togo, 8(1): 9-18.

D'Almeida M-A, Fantodji A, Koua HK, SankareY, N'diaye SA, Ehouman A.
2008. Etude microscopique du développement embryonnaire du crabe Callinectes amnicola (De Rochebrune, 1883 ; Décapoda Portunidae), des eaux lagunaires de Côte d'Ivoire. Rev. Fr. Histotechnol., 21(1): 59-74.

D'Almeida M-A, Fantodji A, Koua HK, Sankaré Y, N'diaye SA, Ehouman A. 2007. Etude microscopique de la différenciation des testicules du crabe Callinectes amnicola (De Rochebrune, 1883 ; Décapoda Portunidae), des eaux lagunaires de Côte d'Ivoire. Rev. Fr. Histotechnol., 20(1): 83-95.

D'Almeida M-A, Koua HK, Ouattara-Soro SF, Fantodji A, Ehouman A, N'diaye AS. 2014. Caractères généraux et étude histologique du développement embryonnaire $\mathrm{du}$ crabe terrestre, Cardisoma armatum, Herklots, 1851 (Decapoda Gecarcinidae) de Côte d'Ivoire. Afri. Sci. Rev. Int. Sci. Technol., 10(2): 338-355.

D’Almeida M-A, Sankaré Y, Koua HK. 2009. Etude microscopique des organes reproducteurs du crabe mâle de Callinectes amnicola (De Rochebrune, 1883) (Décapoda Portuntdae). J. Rech. Sci. Univ. Lomé Togo., 11(2): 47-61.

D'Almeida M-A, Sankaré Y, Koua HK. 2010. Echelles de maturité sexuelle et différenciation des organes reproducteurs $\mathrm{du}$ crabe femelle Callinectes amnicola (De Rochebrune, 1883 ; Décapoda Portunidae), des eaux lagunaires de Côte d'Ivoire. J. Rech. Sci. Univ. Lomé Togo, 12(1): 27-44.

Dash G, Sen S, Koya KM, Sreenath KR, Mojjada SK, Zala MS, Pradeep S. 2013. Fishery and stock assessment of the three-spot swimming crab Portunus sanguinolentus (Herbst, 1783) off Veraval, Gujarat. Indian J. Fish., 60(4): 17-25.

Davis JA. 2004. Spawning Characteristics of the South African Mud crab Scylla serrata (Forskal) in Captivity. JWAS., 35(2): 120-133.

Dessouassi CE. 2014. Exploitation du crabe Callinectes amnicola au lac Ahémé 
(Rocherbrune, 1883) et données préliminaires sur la biologie de l'espèce. Mémoire pour l'obtention du grade de Master, Faculté des Sciences Agronomiques, Université d'AbomeyCalavi, Bénin, p. 66.

Direction des Pêches. 2001. Annuaire Statistique des Pêches Continentales. MAEP/DP: Cotonou.

Direction de la Production Halieutique. 2016. Bulletin de Suivi de la Pêche Continentale Saison, $1^{\text {er }}$ Trimestre 2016. MAEP/DP: Cotonou.

Direction de la Production Halieutique. 2017a. Bulletin de Suivi de la Pêche Continentale Saison, $2^{\text {ème }}$ Trimestre 2016. MAEP/DP: Cotonou.

Direction de la Production Halieutique. 2017b. Bulletin de Suivi de la Pêche Continentale Saison, $3^{\text {ème }}$ Trimestre 2016. MAEP/DP: Cotonou.

Direction de la Production Halieutique. 2017c. Bulletin de Suivi de la Pêche Continentale Saison, $4^{\text {ème }}$ Trimestre 2016. MAEP/DP: Cotonou.

Edea OG, Gbangboche AB, Hinvi LC, Azando EV. 2015. Breeding of the land crab Cardiosoma armatum (Herklots 1851) in enclosure in Benin. J. Appl. Biosci., $\quad$ 96: $9102-9108$. http://dx.doi.org/10.4314/jab.v96i1.7.

Fischer W, Bianchi G, Scott WB. 1981. Fiches FAO d' Identification des Espèces pour les Besoins de la Pêche Atlantique Centre Est. (vol 6). FAO: Rome.

Gangbè L, Agadjihouèdé H, Chikou A, Senouvo P, Mensah GA, Laleye P. 2016. Biologie et perspectives d'élevage de la crevette géante d'eau douce Macrobrachium vollenhovenii (Herklots, 1857). Int. J. Biol. Chem. Sci., 10(2): 573-598. DOI: http://dx.doi.org/ 10.4314/ijbcs.v10i2.11

George ADI, Abowei JFN. 2009. The Composition, Ranking and Diversity of Callinectes amnicola (De Rochebrune, 1883) Food from Okpoka Creek, Niger Delta, Nigeria. Adv. J. Food Sci. Technol., 1(1): 12-18.
George ADI, Abowei JFN, Inko-Tariah MB. 2009. The Composition in Different Size Groups and Index of Relative Importance (Iri) of Callinectes amnicola (De Rochebrune, 1883) Food from Okpoka Creek, Niger Delta, Nigeria. Int. J. Anim. Veter. Adv., 1(2): 83-91.

Gnimadi A, Egboou P, Dessouassi CE, Gbaguidi A. 2008. Rapport final de l'analyse de la chaine de valeur sur la filière crabe (Callinectes et Cardiosoma) au Sud du Benin. Ministère de l'Agriculture, de l'Elevage et de la Pêche/Direction des Pêches, Cotonou.

Goussanou A, Bonou AG, Chikou A, Gandonou P, Mensah G-A, Youssao AKI. 2017a. Morphological, structural characteristics and growth relationship of crab Callinectes amnicola and Cardiosoma armatum in the complex Nokoué lake Porto-Novo lagoon in South Benin. J. Appl. Biosci., 118: 11803-11816.

Goussanou A, Chikou A, Ogni CA, Kassa KS, Houessionon B, Mensah G-A,Youssao AKI. 2017b. Synthèse des connaissances sur l'écologie et la biologie des crabes (Crustacés, Décapodes, Brachyoures). Int. J. Biol. Chem. Sci., 11(6): 29903004. DOI: https://dx.doi.org/10.4314/ ijbcs.v11i6.35

Hardman-Mountford NJ, Mcglade JM. 2002. Variability of physical environmental processes in the Gulf of Guinea and implications for fisheries recruitment: An investigation using remotely sensed sea surface temperature. In Environmental Forcing and Sustainable development of Marine Resources. Elsevier: The Netherlands; 49-66.

Hounga GS. 1999. Etudes de quelques paramètres écoéthologiques du crabe terrestre Cardisoma armatum (Herklots, 1851). Mémoire de fin d'études CPU/Université Nationale du Bénin, Abomey-Calavi, p. 67

Hountogan E. 2012. Diversité et exploitation des crabes du lac Nokoué au Bénin. Mémoire pour l'obtention du grade de 
Master, FSA, Université d'AbomeyCalavi, p. 74.

Jimoh AA, Ndimele PE, Lemomu IP, Shittu UA. 2014. The biology of Gladiator swimming crab (Callinectes pallidus) from Ojo Creek, southwestern Nigéria. $J$. Fish Aquat. Sci., 9(4): 157-169. DOI: 10.3923/jfas.2014.157.169

Jivoff P, Hines AH, Quackenbush LS. 2007. Reproduction biology and embryonic development of Callinectes sapidus. In The Blue Crab Callinectes Sapidus, Kennedy VS, Cronin LE (eds). Maryland Sea Grant College: Maryland; 255-298.

Kwei EA. 1978. Size composition, growth and sexual maturity of Callinectes latimanus (Rath.) in two Ghanaian lagoons. Zool. J. Linn Soc., 64(2): 151175. https://doi.org/10.1111/j.10963642.1978.tb01066.x

Lalèyè PA, Villanueva MCS, Entsua-Mensah M, Moreau J. 2007. A review of the aquatic living resources in Gulf of Guinea lagoons, with particular emphasis on fisheries management issues. $J$. Afrostrop. Zool., Special issue: 123-136.

Lawal-Are AO, Nwankwo H. 2011. Biology of the Hairy Mangrove Crab, Sersema Huzardi (Decapoda: Graspidae) from a Tropical Estuarine Lagoon. J. Am. Sci. Science, 7(7): 402-408.

Le Loeuf P, Intes A. 1968. La faune benthique du plateau continentale de Côte d'Ivoire récoltés au Chalut, abondancerépartition-variations saisonnières (Mars 1966-Février 1967). Document Scientifique Provisoire. $\mathrm{N}^{\circ} 025$. Centre de Recherches Océanographiques. Abidjan.

Lhomme F. 1994. Les crustacés exploitables. In Environnement et Ressources Aquatiques de Cote-d'Ivoire: Les Millieux Lagunaires (Tome II)- Editions ORSTOM: Paris; 229-238.

Manning RB, Holthuis LB. 1981. The West African Brachyuran Crabs Crustacea Decapoda. Smithsonian Institution Press: Washington.

Mensah DE. 2014. Structures de la population $\mathrm{du} \quad$ crabe Callinectes amnicola (Portunidae) à la lagune côtière de Ouidah (Sud-Bénin). Mémoire présenté pour l'obtention du Diplôme de Licence Professionnelle en Hydrobiologie Appliquée (L.H.B.A). Faculté des Sciences et Techniques (F.A.S.T)/Département de Zoologie, Université d'Abomey-Calavi, p. 53.

Mensah GA, Gbeto H. 2001. Actogramme du Crabe Cardiosoma armatum. Actes de l'Atelier Scientifique (2 ${ }^{\text {ème }}$ édn). Institut National des Recherches Agricoles du Bénin: Abomey-Calavi.

Mirera DO. 2014. Capture-based mud crab (Scylla serrata) aquaculture and artisanal fishery in East Africa Practical and ecological perspectives. Linnaeus University Dissertations No 159/2014. Doctoral dissertation, Department of Biology and Environmental Science, Linnaeus University, Kalmar, p. 280.

Monod T. 1956. Hippidea et Brachyura ouestafricain. Mémoire de l'Institut Français d'Afrique Noire, $\mathrm{N}^{\circ} 45$, IFAN: Dakar.

Muller RG, Bert TM, Susan DG. 2006. The 2006 Stock Assessment Update for the Stone Crab, Menippe spp., fishery in Florida. Florida Fish and Wildlife Conservation: St. Petersburg.

Murai T, DegbeyJ-B, Hounkpè C. 2003. Atlas des Poissons et Crustacés du Bénin. Eaux Douces et Saumâtres. MAEP/DP: Cotonou.

Ng PKL, Guinot D, Davie PJF. 2008. Systema Brachyorum: Part I. An annoted checklist of extant brachyuran crabs of the world. Raffles B. Zool., 17: 1- 286.

Olakolu F, Fakayode O. 2014. Aspects of The Biology of blue crab Callinectes amnicola (Rochebrune, 1883) in Lagos lagoon, Nigeria. IJAS., 5(1): 77-82.

Omuvwie U, Atobatele OE. 2013. Growth pattern, condition factor, trace metal studies and ectoparasitic load of the blue crab, Callinectes amnicola from Lagos Lagoon, Badore, Ajah, Lagos, Nigeria. $J$. Exp. Biol., 09(01): 34-43. DOI:http://dx.doi.org/10.4314/cajeb.v9i1 .5 
Onyekachi EM, Edah B. 2014. Food and Feeding Habits, Growth Pattern and Fecundity of Callinectes amnicola in Lagos Lagoon. Adv Plants Agric Res., 1(1) : 1-7.

Pochet B. 2017. Comprendre et Maîtriser la Littérature Scientifique. Les Presses Agronomiques: Gembloux.

Sankaré Y. 2005. Catalogue illustré pour l'identification des crabes d'eau douce et (Côte d'Ivoire). Doc. Sci. Centre Rech. Océanogr, Abidjan, 35-42.

Sankaré Y. 2007. Biologie, écologie et exploitation du crabe nageur Callinectes amnicola, de Rocherbrune, 1883 (Crustacea-Decapoda-Portunidae) du complexe lagunaire Aby-Tendo-Ehy (Côte d'Ivoire). Thèse de Doctorat, Université de Cocody, Cocody, p. 274.

Sankaré Y, Amalatchy NJ, Koffie-bikpo CY. 2014a. Etude comparative des captures de crabes nageurs Callinectes amnicola (Decapoda -Portunidae) des lagunes ivoiriennes (Afrique de l'Ouest). Rev. CAMES, Sciences de la Vie, de la Terre et Agronomie, 01(1): 75-84.

Sankaré Y, Konan KJ, Amalatchy NJ, Soro MB. 2014b. Swimming crab Callinectes amnicola (Decapoda-Portunidae) capture analysis of a lagoon with high continental influence (Aby lagoon, Cote d'Ivoire, West Africa). Wyno Academic Journal of Biological Sciences, 2(2): 919.

Santhanam R. 2018. Biology and Culture of Portunid Crabs of World Seas. Apple Academic Press: Waretown.

Sara L. 2010. Study on the size structure and population parameters of mud crab Scylla serrata in Lawele bay, Southeast Sulawesi, Indonesia. Coast Dev Journal., 13(2): 133-147.

Shahdadi A, Schubart CD. 2017. Taxonomic review of Perisesarma (Decapoda:
Brachyura: Sesarmidae) and closely related genera based on morphology and molecular phylogenetics: new classification, two new genera and the questionable phylogenetic value of the epibranchial tooth. Zool. J. Linn Soc., 20: 1-32. https://doi.org/10.1093/ zoolinnean/zlx032

Sohou Z, Hinvi LC, Ahoyo N, Mensah GA. 2016. Elevage de Crabes d'Eau Portunus Validus et Callinectes amnicola au Bénin. CBRST: Cotonou.

Sparre P, Venema SC. 1998. Introduction to Tropical fish Stock Assessment. Manual FAO Fisheries. Technical Paper. No.306/1. (Part 1, Rev. 2). Food and Agriculture Organization (FAO): Rome.

Thiam N, Diallo A. 2010. Intégration de la Biodiversité d'Eau Douce dans le Processus de Développement en Afrique. Module de Formation des Formateurs sur les Crabes d'Eau Douce. Wetlands International Afrique: Dakar.

Udoh JP, Nlewadim AA. 2011. Population characteristics of the swimming crab Callinectes amnicola, Rocheburne, 1883 (Crustacea, Brachyura, Portunidae) in the Qua Iboe River estuary, Nigeria. AACL Bioflux., 4(3): 412-422. http://www.bioflux.com.ro/accl

Wiegleb V. 2016. A Literature Review on Wetlands in Accra. Water Power Working Paper, No. 5. Governance and Sustain-ability Lab. Trier. Water Power Working Paper Series, 5(1): 1-34.

Williams AB. 1974. The Swimming crabs of the genus Callinectes (Decapoda: Portunidae). Fish. Bull., 72(3): 685699.http://bioportal.naturalis.nl, consulté le $\quad 16 \quad$ février 2018 https://collection.nmnh.si.edu, consulté le 02 mars 2018. 